\title{
Bacterial and parasitic contaminants of salad vegetables sold in markets in Fako Division, Cameroon and evaluation of hygiene and handling practices of vendors
}

\author{
Jane-Francis Tatah Kihla Akoachere*, Bertrand Fossi Tatsinkou and Joseph Mbapngong Nkengfack
}

\begin{abstract}
Objective: Increase in awareness of the health benefits of vegetables has resulted in an increase in consumption. Many vegetables are consumed raw to retain the natural taste and heat labile nutrients. The safety of raw vegetables is a great concern. We investigated the bacteriological and parasitological quality of salad vegetables sold in three major markets in Fako Division Cameroon, the hygiene and preservation practices of vendors and determined the antimicrobial sensitivity of bacterial isolates, to provide data that could be used to improve food safety and safeguard public health.
\end{abstract}

Results: Bacterial contamination was high. Mean aerobic bacteria counts ranged from $2.5 \times 10^{6}$ to $15 \times 10^{6} \mathrm{cfu} / \mathrm{g}$, total coliform counts from 4 to $>2400 / \mathrm{g}$ and fecal coliforms $<3$ to $1100 / \mathrm{g}$. Six bacterial species were isolated among which Staphylococcus aureus (35.4\%) predominated while Serratia marcescens (8.5\%) was the least. Bacteria showed high resistance to erythromycin (87.6\%). Ten parasitic organisms were detected. Balantidium coli (25.6\%) and Entamoeba spp. (21.7\%) predominated. Contamination was highest in lettuce and lowest in green pepper. Hygiene and vegetable preservation practices of vendors were poor and could aggravate contamination. Contamination of fresh salad vegetables with pathogenic bacteria and parasites could be a food safety concern in study area.

Keywords: Salad vegetables, Pathogenic bacteria, Antibiotic resistance, Intestinal parasites, Hygiene practices, Cameroon

\begin{abstract}
Introduction
Vegetables have health promoting characteristics [1, 2], being a source of vitamins and minerals, and phytochemicals some of which are antioxidant, phytoestrogens and anti-inflammatory agents. The recent increase in awareness of the health benefits of vegetables has resulted in increased consumption. Insufficient consumption of fruit and vegetable contributes to poor health and increases the risk of noncommunicable diseases [3]. Consumption of vegetables as part of a diet contributes to weight loss [4] reducing the risk of obesity, a risk factor for noncommunicable diseases. Because of their health benefits,
\end{abstract}

*Correspondence: jakoachere@yahoo.com

Department of Microbiology and Parasitology, Faculty of Science,

University of Buea, PO Box 63, Buea, South West Region, Cameroon
WHO and FAO in 2003 launched a global initiative to promote the consumption of fruits and vegetables [5].

A lot of vegetables are consumed raw as salad to retain the natural taste and heat labile nutrients. The safety of vegetables eaten raw is a great concern as they have been shown to harbor pathogenic bacteria [6-10] and parasites [11-16]. Poor hygienic practices in the production and post-harvest system contribute to contamination [17, 18]. There are documented outbreaks of human infections associated with the consumption of raw vegetables [19]. Trade has contributed to geographic spread of these pathogens [20]. Recent years have witnessed an increase in the frequency of occurrence of these infections. Studies in developed and developing countries have demonstrated the potential of raw vegetables to transmit 
pathogens $[8,9,21-23]$. Data on microbial quality of vegetables in Cameroon is scarce despite the fact that it has witnessed an increase in vegetable consumption and cultivation, as cultivation in addition to ensuring food security, has become an income generating activity [17, 24]. Recent studies in Cameroon have reported the use of contaminated water for irrigation of vegetables [18, 25-28]. Thus, there is an urgent need to evaluate microbiological safety of salad vegetables sold in Cameroon. This study was aimed at investigating the microbiologic quality of salad vegetables from markets in Fako, Division Cameroon, to highlight their potential in disease transmission and provide data that could guide policy to improve food safety and safeguard public health. The hygiene and preservation practices of vendors were also investigated.

\section{Main text \\ Methods \\ Study area and study design}

The study was conducted in three towns in Fako, Cameroon: Buea, Tiko and Limbe. Buea, the capital of Southwest region is located on the eastern slopes of Mount Cameroon. According to data from the Cameroon Development Corporation (CDC) annual rainfall in Buea varies between 3000 and $3500 \mathrm{~mm}$. Buea being the capital of former West Cameroon receives tourists who visit historic sites as well as Mount Cameroon.

Limbe is situated along the Atlantic coast of West Africa. It is bordered in the north by Buea, east by Tiko, west by Idenau and south by the Atlantic Ocean. Limbe and Buea have recently experienced an expansion in hotel and restaurant business as these towns have been hosting many national and international events.

Tiko is located $21 \mathrm{~km}$ from Limbe, and has a temperature range of $35-37^{\circ} \mathrm{C}$. Limbe and Tiko have warm equatorial climatic conditions. Humidity is as high as $80 \%$.

Six vegetable types were purchased weekly from randomly selected vendors in three markets: Buea Central Market, Tiko Market and Limbe Market, for a period of 10 weeks from October to December 2015 and analyzed for bacteria and parasite contamination. The antimicrobial susceptibility of bacteria isolates and the hygiene and preservation practices of vendors were investigated.

\section{Sample collection and processing}

Thirty samples each of cucumber, carrot, lettuce, green pepper, green cabbage and red cabbage were purchased from randomly selected vendors. One sample of each vegetable was collected per week per site for 10 weeks (total of 180 samples). Each sample was placed in a sterile polythene bag and transported to the laboratory at temperature range $4-6{ }^{\circ} \mathrm{C}$. Twenty-five grams of sample was immersed in $225 \mathrm{ml}$ of sterile distilled water for $15 \mathrm{~min}$, vigorously agitated and waste water used for analyses.

\section{Enumeration of aerobic bacteria, total coliforms and fecal coliforms}

Aerobic bacterial count was determined by the pour plate method using nutrient agar (Liofilchem ${ }^{\circledR}$ s.r.l., Italy). A $10^{-4}$ dilution of waste water was prepared and $1 \mathrm{ml}$ inoculated. Plates were incubated at $37^{\circ} \mathrm{C}$ for $24 \mathrm{~h}$.

Undiluted wash water was used for the enumeration of coliforms. Total and fecal coliforms were enumerated by the multiple fermentation test [29].

\section{Isolation and identification of bacteria}

The following media from Liofilchem ${ }^{\circledR}$ s.r.l. (Italy) were used: nutrient agar, MacConkey agar, Salmonella-Shigella agar and mannitol salt agar. Agar plates were inoculated in duplicate with $100 \mu \mathrm{l}$ of sample by the spread plate technique. Prior to inoculation of Salmonella-Shigella agar, samples were pre-enriched overnight in selenite $\mathrm{F}$ broth (Becton, Dickinson \& Company) at $37{ }^{\circ} \mathrm{C}$. Plates were incubated at $37^{\circ} \mathrm{C}$ for $24 \mathrm{~h}$. Pure cultures were characterized by Gram staining, motility, oxidase and catalase tests, and growth on triple sugar iron agar (Oxoid) [30]. Gram positive cocci were subjected to the coagulase test. The identity of gram negative rods was confirmed using the Analytical Profile Index 20E (Biomérieux SA, France) kit.

\section{Antimicrobial susceptibility testing}

The standard disc diffusion technique [31] was used. The following antibiotic discs from Oxoid (Basingstoke, England) were used: erythromycin $(10 \mu \mathrm{g})$, gentamycin $(30 \mu \mathrm{g})$, ampicillin $(10 \mu \mathrm{g})$, ciprofloxacin $(5 \mu \mathrm{g})$, chloramphenicol $(30 \mu \mathrm{g})$ and streptomycin $(10 \mu \mathrm{g})$. The diameters of inhibition zones were compared with those of the Clinical Laboratory Standards Institute (CLSI) [32].

\section{Parasitological examination}

Undiluted waste water was poured through sterile gauze and left for about $10 \mathrm{~h}$ to sediment. The supernatant was discarded and sediment centrifuged at $1207 \times g$ for $5 \mathrm{~min}$. A drop of the sediment as well as iodine stained smears were examined microscopically. Identification was based on their morphology [33].

\section{Evaluation of hygiene and preservation practices of vendors}

A questionnaire was administered to 60 vendors $(20$ from each market), randomly selected from those samples were obtained. Data was also collected by visual inspection. 


\section{Data analysis}

Data was entered in Epi Info version 3.5.3 and exported to SPSS version 20. The ANOVA test was used to compare differences in mean aerobic bacterial counts between various types of vegetables. The Bonferroni corrected post hoc $t$ test (significance at $\mathrm{P} \leq 0.0083$ ) was used to compare the means of aerobic bacterial counts, total coliform counts and fecal coliform population of vegetables from various sites. The Chi square test was used to examine differences in the occurrence of bacterial isolates and parasites. Values were considered significant at $\mathrm{P} \leq 0.05$.

\section{Results}

\section{Aerobic bacterial, total coliform and fecal coliform load of samples}

Aerobic bacteria counts were high, ranging from $2.5 \times 10^{6}$ to $15 \times 10^{6} \mathrm{cfu} / \mathrm{g}$. Lettuce had the highest mean count $\left(9.5 \times 10^{6} \mathrm{cfu} / \mathrm{g}\right)$ while green pepper had the lowest $\left(5.2 \times 10^{6} \mathrm{cfu} / \mathrm{g}\right)($ Fig. 1). ANOVA test showed a significant difference in counts between vegetables $(\mathrm{P}=0.00)$.

The overall mean total coliform count was highest in lettuce $(1171.6 \pm 117.16 / g)$. In Tiko, mean counts were significantly higher in green cabbage $(\mathrm{P}<0.0083)$ while in
Limbe and Buea, counts were significantly higher in lettuce (Table 1).

Fecal coliforms were detected in all samples. Carrots and lettuce had highest count $(248.9 \pm 397.72$ and $165.03 \pm 270.95 / g$ respectively). There were no significant differences in counts between vegetables ( $\left.\mathrm{P}^{>}{ }^{>} 0.0083\right)$ (Table 1).

\section{Bacteria isolated}

Six bacteria species were isolated. Staphylococcus aureus $(83.9 \%)$ was the predominant organism while Serratia marcescens (20\%) was the least (Fig. 2). All six species were detected in all vegetable types. S. aureus was most frequently isolated from leafy vegetables while other bacteria were more frequently isolated from carrots.

\section{Antimicrobial susceptibility of isolates}

Ciprofloxacin (95.1\%) was the most active drug. Resistance to erythromycin (75.6\%) was highest. With the exception of 96 isolates of Staphylococcus aureus susceptible to erythromycin, all other bacteria were resistant (Additional file 1). One Shigella isolate was resistant to all antibiotics.

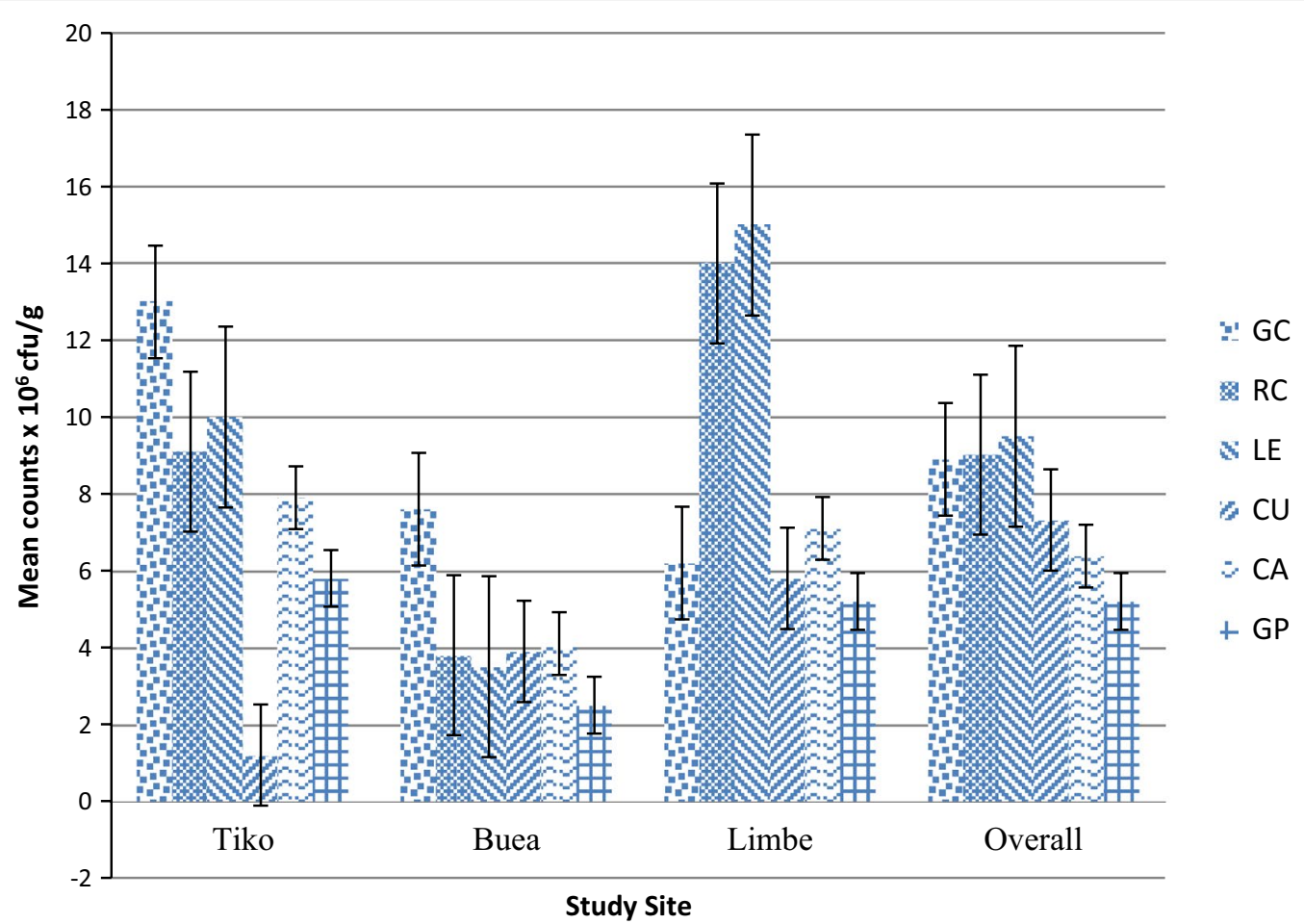

Fig. 1 Mean aerobic bacterial counts ( $\times 10^{6} \mathrm{CFU} / \mathrm{g}$ ) of samples from study sites. Mean aerobic bacterial load of samples was generally high. Highest counts occurred in leafy vegetables green cabbage (GC), red cabbage (RC) and lettuce (LE) compared to non-leafy cucumber (CU), green pepper (GP) and carrots (CA). Number of each sample analyzed $(n)=30$. ANOVA test gave a significant difference $(P=0.00)$ in counts between vegetables 
Table 1 Mean (range) total coliform and fecal coliform load (MPN/g) of sample from various markets

\begin{tabular}{|c|c|c|c|c|}
\hline Vegetable type & Tiko & Buea & Limbe & Mean counts \\
\hline \multicolumn{5}{|l|}{ Total coliforms } \\
\hline Green cabbage & $1536(240$ to $>2400)$ & 430.2 (93 to 1100 ) & $1032.9(93$ to $>2400)$ & $999.7 \pm 1046.15$ \\
\hline Red cabbage & 618 (210 to > 2400) & 199.5 (75 to 210 ) & $1023.9(63$ to $>2400)$ & $613.8 \pm 914.84$ \\
\hline Lettuce & $618(150$ to $>2400)$ & $1448.4(21$ to $>2400)$ & $1448.4(21$ to $>2400)$ & $1171.6 \pm 117.16$ \\
\hline Cucumber & 154.2 (21 to 210$)$ & 152 (20 to 240$)$ & 790.0 (93 to > 2400) & $365.7 \pm 616.24$ \\
\hline Carrot & $1029.3(21$ to $>2400)$ & 94.8 (21 to 210$)$ & $1041.9(63$ to $>2400)$ & $722 \pm 1081.44$ \\
\hline Green pepper & $102.9(28$ to 210$)$ & 103 (4 to 150$)$ & 306.3 (20 to 1100$)$ & $170.73 \pm 264.34$ \\
\hline \multicolumn{5}{|l|}{ Fecal coliforms } \\
\hline Green cabbage & 87.9 (4 to 210$)$ & 27.7 (20 to 39) & 47.3 (7 to 93) & $54.17 \pm 66.55$ \\
\hline Red cabbage & 69.3 (9 to 210 ) & 24.3 (9 to 39) & 22.2 (11 to 28$)$ & $38.6 \pm 58.86$ \\
\hline Lettuce & 115.5 (9 to 240 ) & 291.1 (9 to 1100) & 88.5 (21 to 240$)$ & $165.03 \pm 270.95$ \\
\hline Cucumber & 59.7 (> 3 to 150$)$ & 67.3 (4 to 210 ) & 273.5 (11 to 1100$)$ & $133.5 \pm 272.79$ \\
\hline Carrot & 110.1 (9 to 210 ) & 82.5 (15 to 240$)$ & 554.1 (4 to 1100$)$ & $248.9 \pm 397.72$ \\
\hline Green pepper & 17.3 (9 to 28$)$ & 73.9 (11 to 210$)$ & 50.6 (4 to 39) & $47.27 \pm 62.86$ \\
\hline
\end{tabular}

MPN most probable number

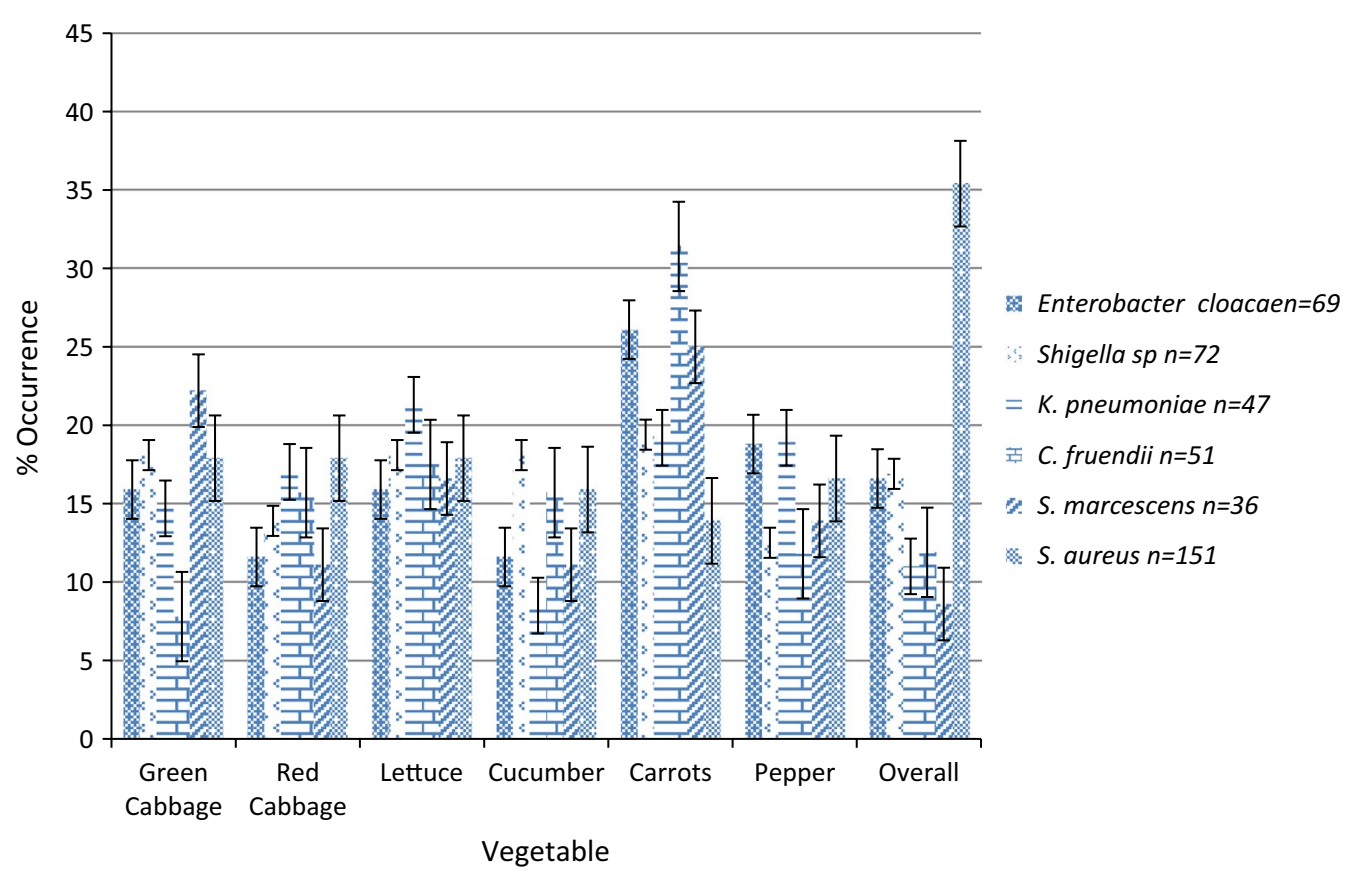

Fig. 2 Distribution of bacteria isolates in samples. Six species of bacteria, mostly enteric organisms were detected in vegetables. S. aureus, the only non-enteric organism was the most frequently isolated. All six species were present in all types of vegetables. Only C. freundii $\left(X^{2}=16.118\right.$, $P=0.007$ ) showed significant differences in the occurrence in various types of vegetables

\section{Contamination with parasites}

Ten parasitic protozoans and helminths were detected. Balantidium coli (32.4\%) was most frequently detected (Additional file 2). With the exception of Trichuris trichiura, all parasites were detected in Buea (Additional file 3). The highest level of contamination occurred in lettuce $(25.4 \%)$ and the least in green pepper (8.5\%)
(Additional file 4). Balantidium coli and Entamoeba spp. were detected in all vegetable types.

Evaluation of hygiene and preservation practices of vendors More females (76.5\%) participated in the survey. The majority of participants $(41.7 \%)$ had no formal education, and did not cultivate the crops (85\%). Hand washing 
with soap was practiced by $23.3 \%$. Only $16.7 \%$ had formal training on hygiene and food preservation (Additional file 5). Washing of vegetables was practiced by $35.0 \%$ amongst which $38.1 \%$ used stream water. None of the vendors transported vegetables to the market or sold them under controlled temperature conditions. Vegetables were placed on dirty bags during sale. Unsold vegetables were kept in the market $(55.0 \%)$ or left in the backyard of their houses (45.0\%).

\section{Discussion}

Samples had high aerobic bacterial counts. Uzeh et al. [34] reported high levels of bacteria in raw vegetables. Bacterial counts were in the order: Lettuce > red cabbage $>$ green cabbage $>$ cucumber $>$ carrot $>$ green pepper. Foods are regarded as harmful when the bacterial load is high even if the bacteria are not known to be harmful [35]. Coliforms were detected in all samples. Mean counts showed a pattern similar to that observed for bacterial load. Lettuce leaves have a large surface area suitable for water, soil and air contact, and fecal droppings from birds making it more susceptible to contamination than the other vegetables. Green pepper is raised above the ground reducing contamination by soil bacteria. Its surface is smooth and surface area small limiting colonization. Highest fecal coliform counts were observed in carrots similar to the report of Weldezgina and Muleta [36]. Carrots being a root crop could have received contamination from the soil, irrigation water, animal wastes used as fertilizer, water used for washing and from handlers. Its pits and crevices retain dirt containing organisms which may not be easily removed by slight washing. Recent studies in Cameroon [25, $26,28]$ report that these vegetables are irrigated with fecally polluted water. Six bacteria species were isolated with Staphylococcus aureus predominating. Apart from Staphylococcus aureus, all isolates are enteric organisms indicating fecal contamination. Similar bacteria have been isolated elsewhere [10, 37, 38]. Isolates were most sensitive to Ciprofloxacin and resistant to erythromycin. One isolate of Shigella was resistant to all six antibiotics tested. Antibiotic-resistant bacteria or resistance determinants are known to spread to humans via the food chain $[39,40]$. Thus raw vegetables could be a source of multi-drug resistant pathogenic bacteria.

Ten species of intestinal parasites were detected. Surveys in other parts of the world have also shown that raw vegetables could be agents for transmission of these parasites [41]. Balantidium coli predominated similar to the report of Simon-Oke et al. [42]. Contrary to our findings, Alade et al. [43] reported a higher prevalence of Ascaris lumbricoides, while Olyaei and Hajivandi [44] reported Toxocara leonine. Similar to Olyaei and Hajivandi [44] we observed a low prevalence of Fasciola spp. and Trichuris trichiura. Leafy vegetables and carrots were more contaminated. Their uneven surfaces facilitate microbial attachment. Similar to Abougraina et al. [45] and Mohamed et al. [14], the highest level of parasite contamination was in lettuce and least in vegetables with smooth surfaces.

Our study showed a higher level of contamination (61.6\%) with intestinal parasites than $13.5 \%$ in Khartoum [14], 36\% in Ghana [46], and 58\% in Tripoli [45]. However, a higher rate of contamination $(75.9 \%)$ was reported in Kenya [47]. The detection of enteric bacteria and parasites in samples implies that they could be contaminated with enteric viruses. The majority of the participants do not practice good hygiene thus increasing the chances of contamination. Transportation to the market was under unhygienic and uncontrolled temperature conditions and this favour the growth of microorganisms [48]. Our study shows that there is an urgent need to sensitize vendors on good hygiene and preservation of vegetables, and the public on proper washing and sanitization of vegetables prior to consumption.

\section{Limitations}

We did not investigate for the presence of other foodborne pathogens such as Listeria monocytogenes, E. coli O157:H7 as well as enteric viruses. We did not include a control strain in susceptibility testing. Also, the minimum inhibitory concentration (MIC) of potent antibiotics was not investigated.

\section{Additional files}

Additional file 1. Antimicrobial susceptibility of bacteria isolates. Bacteria isolated were tested against six antibiotics of different classes. Ciprofloxacin was the most active drug while resistance to erythromycin was highest.

Additional file 2. Occurrence of Parasites in samples. Ten species of parasites at various developmental stages were detected. Balantidium coli was the most frequently detected while Trichuris trichuria was the least.

Additional file 3. Distribution of parasites in study sites. Not all ten species were detected in each study site. Ascaris lumbricoides, hookworm, Strongyloides stercoralis, Balantidium coli and Entamoeba species were detected in all study sites.

Additional file 4. Distribution of parasites in vegetables. All parasites were not detected in all types of vegetables. Only B. coli and Entamoeba species were found in all types of vegetables.

Additional file 5. Characteristics of vendors and hygiene and preservation practices. Hygiene and preservation practices of vendors was poor and this could aggravate contamination.

\section{Abbreviations}

WHO: World Health Organisation; FAO: Food and Agricultural Organisation; CDC: Cameroon Development Cooperation; APHA: American Public Health Association; CFU: colony forming units; MPN: most probable number. 


\section{Authors' contributions}

J-FKTA designed and coordinated the study, analyzed data and drafted the manuscript; BFT designed the study and reviewed the manuscript; JMK collected and analyzed data. All authors read and approved the final manuscript.

\section{Acknowledgements}

We are grateful to Mr. Ojong Samuel of the Clinical Diagnostic Laboratory of the University of Buea, Cameroon for his assistance in parasite identification. We greatly appreciate the vendors of salad vegetables for sacrificing their business time to participate in this study.

\section{Competing interests}

The authors declare that they have no competing interests.

\section{Availability of data and materials}

All data generated or analyzed during this study are included in this published article [and its additional files].

\section{Consent for publication}

Not applicable.

\section{Ethics approval and consent to participate}

Ethical clearance for this study was obtained from the Institutional Review Board Faculty of Health Sciences, University of Buea. All participants were informed about the objectives of the study and their participation was voluntary. Participants signed an informed consent form to indicate their willingness to participate in the study. When necessary, questions were asked in Pidgin English (a local language) and the researcher completed the questionnaire.

\section{Funding}

We received no funding for this study. The study was financed by authors.

\section{Publisher's Note}

Springer Nature remains neutral with regard to jurisdictional claims in published maps and institutional affiliations.

Received: 7 December 2017 Accepted: 12 January 2018

Published online: 06 February 2018

\section{References}

1. Liu RH. Health-promoting components of fruits and vegetables in the diet. Adv Nutr. 2013:4:384S-92S.

2. Slavin $J$, Lloyd B. Health benefits of fruits and vegetables. Adv Nutr. 2012:3:506-16.

3. World Health Organisation (WHO). Increasing fruit and vegetable consumption to reduce the risk of non-communicable diseases. 2016. www. who.int/elena/titles/fruits_vegetables_ncds/en/. Accessed 27 Dec 2016.

4. Whigham LD, Valentine AR, Johnson LK, Zhang Z, Atkinson RL, Tanumihardjo SA. Increased fruit and vegetable consumption during weight and fat loss. Nutr Diabetes. 2012;2(10):e48.

5. WHO/FAO. WHO and FAO announce global initiative to promote consumption of fruit and vegetables. 2016. www.who.int/mediacentre/ news/releases/2003/pr84/en/2003. Accessed 27 Dec 2016.

6. Beuchat LR. Ecological factors influencing survival and growth of human pathogens on raw fruits and vegetables. Microbes Infect. 2002;4(4):413-23.

7. BuckWJ, Walcott R, Beuchat LR. Recent trends in microbiological safety of fruits and vegetables. Online Plant Health Progress. 2003. https://doi. org/10.1094/PHP-2003-0121-01-RV.

8. Cardamone C, Aleo A, Mammina C, Oliveri G, Di Noto AM. Assessment of the microbiological quality of fresh produce on sale in Sicily, Italy: preliminary results. J Biol Res (Thessalon). 2015;22(1):3.

9. Nwanko IU, Eze VC, Onwuakor CE, Friday JU. Evaluation of the degree of contamination of salad vegetatbles sold in Umuahia Main Market. Am J Microbiol Res. 2015;3(1):41-4.
10. Tambekar DH, Mundhada RH. Bacteriological quality of salad vegetables sold in Amravati City (India). J Biol Sci. 2006;6(1):28-30.

11. Amaechi EC, Ohaeri CC, Ukpai OM, Adegbite RA. Prevalence of parasitic contamination of salad vegetables in Ilorin, North Central Nigeria. Momona Ethiopian J Sci. 2016;8(2):136-45.

12. Chau HLQ, Thong HT, Chao NV, Hung PHS, Hai WV, An LV, Fujieda A, Ueru T, Akamatsu M. Microbial and parasitic contamination on fresh vegetables sold in traditional markets in Hue City, Vietnam. J Food Nutr Res. 2014;2(12):959-64.

13. Hafez AA, Asadolahi E, Havasian M, Anahi J, Davoudian A, Lotfikir M, Khosravi $A$. Study on the parasitic and microbial contamination of vegetables, and the effect of washing procedures on their elimination in llam city. J Paramed Sci. 2013:4(4):37-41.

14. Mohamed MA, Siddig EM, Elaagip HA, Edris AMM, Nasr AA. Parasitic contamination of fresh vegetables sold at central markets in Khartoum state. Sudan Ann Clin Microbiol Antimicrob. 2016:15:17.

15. Said DS. Detection of parasites in commonly consumed raw vegetables. Alex J Med. 2012:48:345-52

16. Tamirat T, Abdissa B, Zeleke M, Teferi E. Parasitic contamination of fruits and vegetables collected from selected local markets of Jimma Town, Southwest Ethiopia. Int School Res Notices. 2014;2014:1-7.

17. Beuchat LR. Pathogenic microorganisms associated with fresh produce. J Food Protect. 1996;59:204-16.

18. Temgoua E, Ntangmo TH, Njine T. Vegetable production systems of swamp Zone in Urban Environment in West Cameroon: case of Dschang City. Univ J Environ Res Technol. 2015;2(2):83-92.

19. Lienemann T, Niskanen T, Guedes S, Siitonen A, Kuusi M, Rimhanen-Finne R. Iceberg lettuce as suggested source of a nationwide outbreak caused by two Salmonella serotypes, Newport and Reading, in Finland in 2008. J Food Prot. 2011;74:1035-40

20. Al-Kharousi ZS, Guizani N, Al-Sadi AM, Al-Bululushi IM, Shaharoona B. Hiding in fresh fruits and vegetables: opportunistic pathogens may cross geographical barriers. Int J Microbiol. 2016;2016:14

21. Franz E, Tromp SO, Rijgersberg H, van der Fels-Klerx HJ. Quantitative microbial risk assessment for Escherichia coli O157:H7, Salmonella, and Listeria monocytogenes in leafy green vegetables consumed at salad bars. Food Protect. 2010;73(2):274-85

22. Losio MN, Pavoni E, Bilei S, Bertasi B, Bove D, Capuano F, Farneti S, Blasi G, Comin D, Cardamone C, Decastelli L, Delibato E, De Santis P, Di Pasquale S, Gattuso A, Goffredo E, Fadda A, Pisanu M, De Medici D. Microbiological survey of raw and ready-to-eat leafy green vegetables marketed in Italy. Int J Food Microbiol. 2015;210:88-91.

23. Mritunjay SK, Kumar V. Potential hazards of microbial contamination associated with raw eaten salad vegetables and fresh produces. Middle-East J Sci Res. 2015;23(4):741-9.

24. Asongwei AG, Yerima PKB, Tening AS. Vegetable production and the livelihood of farmers in Bamenda Municipality, Cameroon. Int J Curr Microbiol App Sci. 2014;3(12):682-700.

25. Mewouo YCM, Ewoti OVN, Aboubakar A, Ndjama J, Ngoupayou JRN, Nola M, Ekodeck GE, Togouet SHZ, Bilong P. Microbiological quality of shallow irrigation water at Nkolbisson a sub-urban area of Yaounde (Cameroon): influence of some physicochemical properties. Int J Res Earth Environ Sci. 2014;2(3):8-17.

26. Ntangmo TH, Temgoua E, Njine T. Physico-chemical and bacteriological quality of vegetable watering water in the Dschang Town, Cameroon. J Environ Protect. 2012;3:949-55.

27. Tita MA, Magha A, Kamgang KVB. Microbial pollution of the Mezam river system and its health impact in Bamenda (North-West Cameroon). Afr J Microbiol Res. 2013;7(42):4940-8.

28. Tsama VN, Chewachong MG, Noumsi IMK, Nzouebet WAL, Nyochembeng $\mathrm{N}$, Ambang Z. Contamination of lettuce plants irrigated with waste water in Yaounde, Cameroon. Am J Exp Agric. 2015;6(6):402-9.

29. American Public Health Association (APHA). Standard methods for the enumeration of water and wastewater. 21 st ed. Washington DC: APHA; 2005

30. Cheesbrough M. Microbiological tests: biochemical tests to identify bacteria. District laboratory practice in tropical countries. 2nd ed. Cambridge: Cambridge University Press; 2006. p. 62-70.

31. Bauer AW, Kirby MDK, Sherries JC, Truck M. Antibiotic susceptibility testing by a standardized single disk method. Am J Clin Pathol. 1966:45:493-6. 
32. Clinical and Laboratory Standards Institute (CLSI). Performance standards for antimicrobial susceptibility testing, approved standard, M02-A11, vol. 32. 11th ed. Wayne: Clinical and Laboratory Standards Institute; 2012.

33. Garcia LS. Macroscopic and microscopic examination of fecal specimens. In: Garcia LS, editor. Diagnostic medical parasitology. 5th ed. American Society for Microbiology (ASM): Washington DC; 2007. p. 782-830.

34. Uzeh RE, Alade FA, Bankole M. The microbial quality of prepacked mixed vegetable salad in some retail outlets in Lagos, Nigeria. Afr J Food Sci. 2009;3(9):270-2.

35. Sudershan RV, Rao P, Polasa K. Food safety research in India: a review. Asian J Food Ag-Ind. 2009;2(3):412-33.

36. Weldezgina D, Muleta D. Bacteriological contaminants of some fresh vegetables irrigated with Awetu River in Jimma Town, Southwestern Ethiopia. Adv Biol. 2016;2016:11.

37. Eni AO, Oluwawemitan IA, Solomon OU. Microbial quality of fruits and vegetables sold in Sango Ota, Nigeria. Afr J Food Sci. 2010;4(5):291-6.

38. Meher NN, Reaz MM, Mahmudul H, Fakruddin SI, Habibur RB, Asif I. Prevalence of multi drug resistant bacteria on raw salad vegetables sold in major markets of Chittagong City, Bangladesh. Middle-East J Sci Res. 2011;10(1):70-7.

39. Boehme S, Werner G, Klare I, Reissbrodt R, Witte W. Occurrence of antibiotic-resistant enterobacteria in agricultural foodstuffs. Mol Nutr Food Res. 2004;48:522-31.

40. Tenover FC. Development and spread of bacterial resistance to antimicrobial agents: an overview. Clin Infect Dis. 2001;33(Suppl. 3):108-15.

41. Vuong TA, Nguyen TT, Klank LT, Phung DC, Dalsgaard A. Faecal and protozoan parasite contamination of water spinach (Ipomoea aquatica) cultivated in urban wastewater in Phnom Penh, Cambodia. Trop Med Int Health. 2007;12:73-81.

42. Simon-Oke IA, Afolabi OJ, Obasola OP. Parasitic contamination of fruits and vegetables sold at Akure Metropolis, Ondo State, Nigeria. Researcher. 2014;6(12):30-5.

43. Alade GO, Alade TO, Adewuyi IK. Prevalence of intestinal parasites in vegetables sold in Ilorin, Nigeria. Am Eurasian J Agr Environ Sci. 2013;13(9):1275-82.

44. Olyaei A, Hajivandi L. Parasitological contamination of markets and farms in vegetables consumed in Southern Iran. Global Veterinaria. 2013;10(3):327-31.

45. Abougraina AK, Nahaisi MH, Madia NS, Saied MM, Ghengheshc KS. Parasitological contamination in salad vegetables in Tripoli-Libya. Food Control. 2010;21:760-2.

46. Amoah P, Drechsel P, Abaidoo RC, Klutse A. Effectiveness of common and improved sanitary washing methods in selected cities of West Africa for the reduction of coliform bacteria and helminth eggs on vegetables. Trop Med Int Health. 2007;12(2):40-50.

47. Nyarango RM, Aloo PA, Kabiru EW, Nyanchong B. The risk of pathogenic intestinal parasite infections in Kisii Municipality, Kenya. BMC Public Health. 2008;8:237.

48. Khalil RK, Frank JF. Behavior of Escherichia coli 0157:H7 on damaged leaves of spinach, lettuce, cilantro, and parsley stored at abusive temperatures. J Food Prot. 2010;73(2):212-20.

\section{Submit your next manuscript to BioMed Central and we will help you at every step:}

- We accept pre-submission inquiries

- Our selector tool helps you to find the most relevant journal

- We provide round the clock customer support

- Convenient online submission

- Thorough peer review

- Inclusion in PubMed and all major indexing services

- Maximum visibility for your research

Submit your manuscript at www.biomedcentral.com/submit
( BioMed Central 